\title{
LIFE SKILLS OF YOUNG PEOPLE WITH DISABILITIES AND YOUTH WITHOUT DISABILITIES
}

\section{Izeta Husić-Đuzić Ševala Tulumović ${ }^{1}$ Vesna Bratovčić}

Original scientific paper

DOI: $10.21554 /$ hrr.091701

\author{
Elementary school "Mejdan", Tuzla \\ University of Tuzla, Faculty of Education and Rehabilitation Bosnia and Herzegovina
}

Received: 12.06 .2017

Accepted: 28.07.2017

\begin{abstract}
The aim of this paper is to determine the differences in life skills of young people with and without disability in chronological age from 18-35 year-old in Tuzla Canton. The respondents sample consists of two sub-samples. First sub-sample contains 50 young people with disability, chronological age from 18-35 of both genders. Second sub-sample contained 50 young people without disability, chronological age from 18- 35 of both genders. Research data were analysed using method of parametric and non-parametric statistics. Frequencies, percentages and measures of central tendency have been calculated (arithmetic mean and standard deviation). P-values have been used for examining the difference between variables and variance analysis has been used for examining the importance of differences. The results show that there is a significant statistical difference between young people with and without disabilities in the of life skills assessed: job retention skills, skills to cope in danger. Based on the results obtained, it is recommended to start the program and training in early age which will make life easier to disabled persons and their families.
\end{abstract}

Key words: young people with disability, young people without disability, independence, life skills

\section{INTRODUCTION}

In the world of variety it is general opinion that being different is discriminating in many life spheres. Today, in Bosnia and Herzegovina live large number of people, with different level and type of disability, which are coping with being a part of society. Still, being included in local community does not imply that people with disability ask for additional care of public but, it implies their commitment and possibility to achieve rights as a human and citizen. People with disabilities are spread all over the world and in all levels of society, with share of $10 \%$ of total population (Anić, 2002). Within the ecological concept, around $25 \%$ of population is affected by disability
(Rački, 1996). Word Disability implies “ any limitation or ability reduction in undertaking any activity, in the way, or within scope, which is considered normal for human being". Disabled person, though, is a person with disability (Rački, 1997). Disabled person is any person with different body, thought or mind state or illness which permanently disables the fulfilment of personal and social need in everyday social and economy life (Žunić, 2001). Expression disability, as well as the earlier "defect", however, still has a negative connotation besides other personal characteristics, where imitation, impediment and disability are put forward (Zovko,1990).

\footnotetext{
${ }^{1}$ Correspodence to:

Ševala Tulumović, Faculty of Education and Rehabilitation, University of Tuzla

Univerzitetska 1, 75000 Tuzla, Bosnia and Herzegovina

Phone: +38735320673

E-mail: sevala.tulumovic@untz.ba
} 
In the last few decades, in our society, at least three common models in the approach to disability phenomenon which are mutually intertwined and they affect the relationship between the community and disabled people, as well as relationship between disabled people towards disability phenomenon and themselves (Zahirović et al., 2009). In order to determine the base for standardized assessment of functioning and the interaction with the environment it is necessary to make a specification for each separated function, activities and factors of environment when def In order to achieve the basis for a standardized evaluation of the functioning of people, and its interaction with the environment it is necessary for each of the outsourced functions, activities and environmental factors to make a specification of when the damage on the observed variable does not exist, when the damage is mild, moderate, or strong/ total (Strnad \& Benjak, 2010). The philosophy of independent living of people with disabilities is based on the principle that people with disabilities are not passive recipients of care and aging, but people who can and have the right to control their own lives, to make choices, make decisions and take responsibility for them (Dinkić \& Momčilović, 2005). The main principles of philosophy of independent living of people with disabilities are: choice, making a decision, control, responsibility and the right to make a mistake. The preconditions for an independent living for people with disabilities are: the possibility of obtaining relevant information, the possibility of exchanging experiences with other people with disabilities, the existence of accessible housing, the existence of technical aids, the existence of an accessible architectural environment, the existence of accessible transport, the existence of personnel assistant service (Vučenović \& Mastikosa, 2015). The philosophy of independent living is the result of efforts of the disability movement to see the issue of disability as a human rights issue (Lučić, 2009). Skill is the ability of an individual to quickly and accurately perform a series of gradually organized operations or assembly operations for more easily and efficiently performing a task. Social skills enable people to know what to say, how to make good choices and how to behave in different situations (Ferić- Šlehan \& Kranželić, 2005). Self-esteem in people with disabilities is defined as assessment of their own capacities to function in a social environment (Omolayo, 2009). Activities of daily living include tasks for which a person regularly prepares or as an addition for participation in his or her social roles and work in everyday life (Trombly, 1995). Social skills are one of the most important factors of development of identity (Erikson, 2008). The management of social interactions is one of the most complex tasks that people do, and it implies the inclusion of many physiological systems such as visual and auditory perception, speech and problem solving (Masty \& Schwab, 2006).

\section{THE AIM OF THE RESEARCH}

The aim of this paper is to determine the differences in life skills in young people with and without disabilities.

\section{WORK METHODS}

\section{The sample}

The sample of correspondents consisted of two subsamples. First subsample contains 50 young people with disability, chronological age from 18-35 of both genders. Second sub-sample contained 50 young people without disability, chronological age from 18-35 of both genders randomly selected in Tuzla Canton.

\section{The sample of variables:}

It is analysed 2 variables in total: job retention skills, skills to cope in danger.

\section{The method of conducting research}

The research has been conducted in the time period of two months during which the research took place on the field. Each respondent answered the questions individually after previous instructions of interviewer. Respondents were asked to express their agreement or disagreement, or the level of agreement or disagreement with the views expressed in the claims. Young people with disabilities were interviewed individually. The time that was scheduled for an interview with each respondent was 15-25 minutes. Young people without disabilities were interviewed in groups. Time for filling in the questionnaires provided by this study is 15 minutes. All respondents are familiar with the research and are informed on how to complete the questionnaire. 


\section{Measuring instruments}

Life skills inventory was used for the purpose of this study and it examines life skills (Life skills inventory /Independent Living Skills Assessment Tool - Department of social and health services-Washington State, 2000), in certain categories that are necessary for independent living, Multidimensional scale of perceived social support (Zimet et al, 1988).

\section{Data processing methods}

Research data obtained were analysed using method of parametric and non-parametric statistics. Frequencies, percentages and measures of central tendency have been calculated (arithmetic mean and standard deviation). P-values have been used for examining the difference between variables and variance analysis has been used for examining the importance of differences. Data are shown in the table. Data are obtained in statistical analysis software package SPSS 16 for Windows.

\section{RESULTS}

Results obtained in table 1 show that there is a statistically significant difference between the existence of disability and level of efficiency in performing a skill related to job keeping. In a sample of young people with disabilities there are evident issues related to skills in anger management in crisis situations, seeking a raise, communication with superiors. A minor percentage of respondents with an extraordinary efficiency performance in the skill mentioned is evident for people with disabilities than without.

Table 1 The difference between respondents in the art of job retention

\section{JOB RETENTION}

\begin{tabular}{|c|c|c|c|c|c|c|c|c|c|c|}
\hline \multirow{2}{*}{$\begin{array}{l}\text { Group of } \\
\text { respondents }\end{array}$} & \multicolumn{2}{|c|}{ Primary } & \multicolumn{2}{|c|}{ Central } & \multicolumn{2}{|c|}{ Advanced } & \multicolumn{2}{|c|}{ Exceptionally } & \multicolumn{2}{|c|}{ Total } \\
\hline & $\mathbf{f}$ & $\%$ & f & $\%$ & f & $\%$ & $\mathbf{f}$ & $\%$ & f & $\%$ \\
\hline $\begin{array}{l}\text { Persons without } \\
\text { disabilities }\end{array}$ & 0 & 0,00 & 0 & 0,00 & 0 & 0,00 & 50 & 100,00 & 50 & 100,00 \\
\hline $\begin{array}{l}\text { People with } \\
\text { disabilities }\end{array}$ & 11 & 22,00 & 13 & 26,00 & 2 & 4,00 & 24 & 48,00 & 50 & 100,00 \\
\hline
\end{tabular}

Results obtained in the table 2 show that there is a statistically significant difference between the existence of disability and level of efficiency in performing a skill related to coping in danger. In a sample of young people with disabilities there are evident issues related to skills in usage of fire extinguisher, a gas leak procedures, providing first aid and resuscitation. A minor percentage of respondents with an extraordinary efficiency performance in the skill mentioned is evident for people with disabilities than without.

Table 2 The difference between respondents in the art of coping with dangers

\section{GETTING AROUND IN DANGER}

\begin{tabular}{|c|c|c|c|c|c|c|c|c|c|c|}
\hline \multirow{2}{*}{$\begin{array}{l}\text { Group of } \\
\text { respondents }\end{array}$} & \multicolumn{2}{|c|}{ Primary } & \multicolumn{2}{|c|}{ Central } & \multicolumn{2}{|c|}{ Advanced } & \multicolumn{2}{|c|}{ Exceptionally } & \multicolumn{2}{|c|}{ Total } \\
\hline & $\mathbf{f}$ & $\%$ & $\mathbf{f}$ & $\%$ & f & $\%$ & f & $\%$ & $\mathbf{f}$ & $\%$ \\
\hline $\begin{array}{l}\text { Persons without } \\
\text { disabilities }\end{array}$ & 0 & 0,00 & 0 & 0,00 & 0 & 0,00 & 50 & 100,00 & 50 & 100,00 \\
\hline $\begin{array}{l}\text { People with } \\
\text { disabilities }\end{array}$ & 18 & 36,00 & 3 & 6,00 & 13 & 26,00 & 16 & 32,00 & 50 & 100,00 \\
\hline
\end{tabular}




\section{DISCUSSION}

The research includes people with disabilities and people without disabilities. In a sample of people with disabilities the most represented are people with cerebral palsy (40\%), followed by multiple sclerosis (24\%), spinal cord injuries (16\%), muscular dystrophy (10\%), multiple disabilities (4\%), amputation (4 $\%$ ), and visual impairment (2\%). Young people with and without disability differ in level of qualification. Most young people with disabilities who are included in this study have a high school education according to regular curriculum and plan of education $(72 \%)$, while young people without disabilities mostly tend to have a university degree $(76 \%)$. Young people without disabilities are more interested in further education and improvement (52\%) compared to young people with disabilities (44\%). A very small percentage of young people with disabilities are using assistive technology in their daily activities (4\%). Only $4(8 \%)$ of young persons with disabilities from the test sample is employed, but the problem of unemployment is expressed among young adults without disabilities, although, 19 young people (38\%) from test sample is employed. A significant percentage of young people without disabilities (44\%) are financially supported by their parents, and the respective percentage of people with disabilities is even higher $(58 \%)$. A disturbing fact is that $(6 \%)$ of young people with disabilities does not have any income, and $14 \%$ receive care and assistance, which is their only income. The research results show that there is a significant statistical difference between young people with and without disabilities in the majority of life skills assessed: household management, culture of living, transport, education planning, job search skills, job retention skills, skills to cope in danger, interpersonal skills, family and parenting planning. Although results have shown that a minor percentage of respondents with disability is familiar with resources of local community and the laws that define their rights and obligations than respondents without disabilities, there is not statistically significant difference between these groups of respondent in the skills mentioned. Reason for that can be found in the fact that young people with disability, included in the research, are members of organisations through which they get informed about their rights and resources in the local community. in the research obtained related to the field "self-care" it is concluded that young people with disability are better in assessment of possi- bilities to get things done in their own way and when they want, in comparison to their parents. Larger percentage of young people with disability $(67,5 \%)$ is considered to be able to take care of themselves: to make a meal, keep the hygiene, keep the house and clothes clean, when compared to their parents. On the other hand, the same research states that parents believe that young people with disabilities can make decisions about their movements, where and when they want (with or without additional aids or assists), whereas young people with disabilities disagree. The least choice that they have, young people with disabilities have expressed in terms of possibility to go on trips and vacations that they want, which are assessed as "very bad". Results related to the use of money show that young people with disabilities are having issues with control of money spending, compared to their parents. When asked whether there is any amount of money on which they can decide for themselves, the majority of respondents, included in this study, responded negatively (Bratovčić \& Mehmedinović, 2015). According to research conducted, "Comparative research on quality of employment of people with disability", results have shown that of the total number of respondents, $92.2 \%$ answered the question which relates to the assistance of others in performing activities of daily living. More than half of this number is considered that they did not need any help of others in carrying out these activities (63.3\%). Respondents who indicated that they need assistance in activities of daily living, it is largely related to administrative affairs, going out places of residence, housework, movement and transportation. When observing the assistance needed, it is evident that employed persons who need assistance in performing basic household work (personal hygiene, toilet, dressing and transfers and etc) almost do not exist since for over $90 \%$ of respondents the assistance is not necessary. This was expected since the sample contains in over $50 \%$ persons with sensory and intellectual impairment, who don't need this kind of help. Therefore, this report confirms the fact that the most difficult persons to employ and the least number of employed persons are the ones with a higher level of disability. Regarding the fact that the sample is about $30 \%$ of people with physical impairments that mainly lead to these needs, but only $10 \%$ of them, is in need of basic assistance, therefore, this conclusion is more likely, because even person with this type of disability tend to employ those who have a lower level of impairment (Ljubinković, 2009). 
In a study conducted in the field of functional life skills among young people with multiple and mild disabilities, which included housekeeping, participation in community and recreation, the results showed that young people with multiple disabilities needed more sessions (12-50) than young people with milder issues, which is supposed to lower the number of sessions for mastering the skills listed (Cobb et al, 2006). Furthermore, research in the field of "Education and Training" has shown that parents of young people with disabilities better assess the possibility for further education and training than young people with disabilities. Young people estimate that their opportunities for additional training and education are poor due to distance from urban centres, the inaccessibility of public transportation, inaccessibility of environment and institutions, poor financial situation and prejudice against persons with disabilities (Bratovčić i Mehmedinović, 2015). The study "Unlimited- Survey for people with disabilities and employers' shows that in order to find employment, people with disabilities are usually informed about available job positions through Employment Agency (109 persons, 60.9\%), followed by inquiring with friends and acquaintances if they know of any job position (92 persons, 51.4\%), and track ads on job position in newspapers (64 persons, $35.8 \%$ ), Internet (56 persons, $31.3 \%$ ), 35 of them $(19,6 \%)$ personally contacted various employers for the purpose of employment or searching for influential people to help them in employment ( 27 persons, $15.1 \%)$. The least contacted are private employment agencies ( 2 persons, 1,1\%), exploring the possibility of starting your own business (9 persons, 5.0\%), addressing the associations of persons with disabilities to help in finding a job (12 people, $6,7 \%)$, provide ads to job seekers (13 persons, $7.3 \%$ ), inform about incentives for employment of disabled persons (17 persons, $9.5 \%)$. It is interesting that 15 of them $(10.1 \%)$ do nothing with regard to job search, while 6 persons (3.4\%) did not answer this question (Blažinić-Papišta, 2011). While in the research conducted where the results showed the absence or underdevelopment of the following social skills affect the labour and social integration of people with disabilities, and therefore affects the retention of employment: the lack of communication skills leads to disagreements and misunderstandings; inadequate relationship with colleagues leads to isolation, making it difficult to cooperate in the performance of their tasks, and affects the quality and efficiency of the completion of some work. Certain social skills (social rules) are directly related to work performance, such as: compliance with the working hours, compliance with time for a break, good interpersonal relationships with colleagues and superiors, listening to instructions, accepting criticism and more. All mentioned above implies the need for the development of social skills in young people with disabilities, as well as their efficiency and productivity (Arsenović \& Pantelić, 2014).

\section{CONCLUSION}

Based on the research results there is a following conclusion: The results in this research show that there is a significant statistical difference between young people with and without disabilities in the of life skills assessed: job retention skills, skills to cope in danger. Based on the results obtained, for young people with disabilities it is recommended to start the rehabilitation program and training on developing and adopting life skills at early age in order to increase the feeling of success and safety and to create conditions for safe success in the further education and quality of their lives.

\section{REFERENCES}

Anić, V. (2002). Hrvatski enciklopedijski rječnik. Zagreb: Novi Liber.

Arsenović, D., \& Pantelić, M. (2014). Uticaj razvijenosti socijalnih vještina osoba sa invaliditetom na radnu $i$ socijalnu integraciju. Beograd: Lola Preduzetništvo.

Blažinić-Papišta, T. (2011). Project UNLIMITED. Analiza anketnih upitnika za osobe sa invaliditetom i poslodavce. Zagreb: Hrvatska.

Bratovčić, V., \& Mehmedinović, S. (2015). Put ka samostalnosti. Izvještaj o istraživanju o stavovima mladih osoba sa invaliditetom $i$ njihovih porodica o pravima i mogućnostima osoba sa invaliditetom u Tuzlanskom kantonu. Projekat: Jačanje kapaciteta za samostalni život osoba sa invaliditetom u Bih. Tuzla: Informativni centar za osobe sa invaliditetom: Lotos.

Cobb, B., Sample, P. L., Alwell, M., \& Johns, N. R. (2006). Cognitive-behavioral interventions, dropout, and youth with disabilities: A systematic review. Remedial and Special Education 27 (5): 259-275.

Dinkić, M., \& Momčilović, J. (2005). Cijena samostalnosti: Analiza opravdanosti ulaganja u organizovanje servisa personalnih asistenata za pomoć osobama sa invaliditetom u Srbiji. Beograd. [cited 2015] http://www.cilsrbija.org/

Erikson, E.H. (2008). Identitet $i$ životni ciklusi. Beograd: Zavod za udžbenike.

Ferić-Šlehan, M., \& Kranželić, V. (2005). Trening socijalnih vještina. [cited 2015] available from https://view.officeapps.live.com/op/view.aspx?src=http://sestre-sv-kriza. hr/suncev-sjaj/images/prezentacije/Trening_socijalnih_ vjestina.ppt. 
Lučić, M. (2009). Hrvatski kvalifikacijski okvir: Uvod u kvalifikacije. Zagreb: Ministarstvo znanosti, obrazovanja i sporta.

Ljubinković B. (2009). Uporedno istraživanje o kvalitetu zaposlenosti osoba sa invaliditetom. Beograd: Centar za samostalni život invalida Srbije.

Masty, J., \& Schwab, Y. (2006). Changing the face of child mental health. NYU Child Study Centar: NY.

Omolayo, B. (2009). Effects of leadership styles on job related tension and psychological sense of comm unity in work organization: case study of four organization in Lagos State, Nigeria: Bangladesh.

Rački, J. (1996). Osobe s invaliditetom u svijetu rada koji se mijenja. Defektologija; 31:1-2.

Rački, J. (1997). Teorija profesionalne rehabilitacije osoba $s$ invaliditetom. Zagreb: Sveučilište u Zagrebu.

Strnad, M., \& Benjak, T. (2010). Međunarodna klasifikacija funkcioniranja, onesposobljenja $i$ zdravlja. Zagreb:Medicinska knjiga.
Trombly, C. (1995). Occupational therapy for Physical Dysfunction. Baltimore: Maryland.

Vučenović, D., \& Mastikosa, O. (2015). Samostalan život osoba s invaliditetom. Banja Luka. [cited] available from http:// www.ho-partner.rs.sr/brosure/samostala zivot.

Zahirović, S., Čolić, V., Jonjić, D. (2009). Novi pristupi u oblasti invalidnosti: Inkluzija i jednake mogućnosti. Direkcija za ekonomsko planiranje Bosne i Hercegovine, Federalno ministarstvo rada i socijalne politike, Ministarstvo zdravlja i socijalne zaštite Republike Srpske. Sarajevo: Nezavisni biro za humanitarna pitanja.

Zimet, G.D., Dahlem, N.W., Zimet, S.G., Farley, G.K. (1988). The Multidimensional Scale of Perceived Social Support. Journal of Personality Assessment (52), 30-41.

Zovko, G. (1990). Invalidi i društvo. Revija za socijalnu politiku (2), 105-107.

Žunić, Z. (2001). Profesionalnom rehabilitacijom u 21.stoljeće. Državni zavod za zaštitu obitelji, materinstva i mladeži. Zagreb: Ministarstvo rada i socijalne skrbi. 